\title{
The process of dialogue between the Republic of Kosovo and the Republic of Serbia: A review from a constitutional perspective
}

\begin{abstract}
This article aims to present a clear picture of the attempts towards the normalisation of relations in the western Balkans between the Republic of Kosovo and the Republic of Serbia via the process of the dialogue, facilitated by the UN General Assembly and mediated by the EU, which began more than eight years ago. The dialogue has produced different results for both countries so far, including various consequences and implications which have a constitutional nature. Taking this into account, this article offers an analysis of the perspective and the constitutional dimensions of the Kosovo-Serbia dialogue, drawing on the legal and factual actions that have been undertaken by the parties in the process thus far. The article analyses this dialogue and draws conclusions regarding the ending of the process and, in practice, how the final normalisation of relations should look, including the drawing up of a final agreement of reconciliation between the Republic of Kosovo and the Republic of Serbia. The constitutional consequences which can be the product of such an agreement are also examined.
\end{abstract}

Keywords: process of dialogue, constitution, international agreement, implementation of agreements, constitutional changes.

Introduction

Kosovo's declaration of independence on 17 February 2008 opened a new chapter in the relations between Kosovo and Serbia as two different states. That the state of Kosovo was an already-established reality was confirmed by the International Court of Justice (ICJ) which, in its Advisory Opinion of 22 July 2010 regarding Kosovo's declaration of independence, had found inter alia that the declaration was not in violation of international law and did not violate Security Council Resolution 1244 and the Constitutional Framework. ${ }^{1}$

The issue of the ICJ's Advisory Opinion on the declaration and, consequently, the proclamation of Kosovo's independence had created an unfavourable legal position for the Republic of Serbia regarding its relationship with Kosovo. In these circumstances, on 9 September 2010, the UN General Assembly adopted a resolution, which was supported by European Union member states, according to which the

1 International Court of Justice Reports of Judgments, Advisory Opinions and Orders in Accordance with International Law of the Unilateral Declaration of Independence in Respect of Kosovo Advisory Opinion, 22 July 2010, paragraph 120. 
General Assembly accepted the content of the ICJ's Advisory Opinion and, among other things, welcomed the initiation of a process of dialogue between Kosovo and Serbia established to achieve four goals:

- peace and stability in the region

- the promotion of co-operation

- achieving progress on the road towards the EU

- improving the life of the people. ${ }^{2}$

The Resolution of the UN General Assembly is considered to be the first act through which the process of dialogue between the Republic of Kosovo and Serbia began and in which both countries were involved. After the UN Resolution was published, the readiness of the two states to enter a process of dialogue and under the mediation of the EU was clearly seen. For this purpose, both countries took specific steps.

\section{Switching the dialogue process from the technical to the political}

The first step of the Republic of Kosovo in relation to the start of the dialogue with Serbia was the resolution issued by its parliament on 10 March 2011. This resolution supported the dialogue between Kosovo and Serbia, as two independent and sovereign states, and reiterated that the dialogue would only be carried out on technical issues without affecting the sovereignty, territorial integrity and the internal constitutional regulation of the Republic of Kosovo. ${ }^{3}$ In this resolution, it was determined that the leader of the dialogue would be appointed by the Prime Minister. For this purpose, the person in charge of the government was appointed, although the Republic of Kosovo later on created a special ministry responsible for the dialogue with Serbia. This period is known as the stage when the dialogue took place at technical level.

During this period, seven agreements were reached:

1. agreement on free movement

2. agreement on integrated border management (the IBM Agreement)

3. agreement on cadastral registers

4. agreement on civil registers

5. agreement on regional representation

6. agreement on diploma recognition

7. agreement on the mutual recognition of customs stamps.

Meanwhile, discussions on issues related to telecommunications and energy were also initiated (Kosovo Democratic Institute, 2018).

Following a one-year technical dialogue, the parliament of the Republic of Kosovo issued another resolution, on 18 October 2012, on the Normalisation of Relations

2 Resolution adopted by the General Assembly [without reference to a Main Committee (A/64/L.65/Rev. 1)] 64/298: Request for an advisory opinion of the International Court of Justice on whether the unilateral declaration of independence of Kosovo is in accordance with international law, 9 September 2010.

3 Resolution of the Parliament of the Republic of Kosovo No. 04-R-001, Prishtina, 10 March 2011. 
between Kosovo and Serbia. This raised the process to the political level since the resolution stipulated that the dialogue would be led by the government. ${ }^{4}$ Indeed, one day after the adoption of this resolution, there was a meeting between the prime ministers of Kosovo and Serbia. ${ }^{5}$

Thus, the process of dialogue included two main phases: the stage at which the process was considered to be technical; and that when this process continued to the political level, initially at prime minister level and then, later, at presidential level. ${ }^{6}$ During these two phases, in support of the parliamentary resolutions which embodied certain constitutional principles, the government also issued two platforms which supported those same constitutional principles as issues that could not be touched in the process of dialogue, these being: sovereignty; constitutional order; and territorial integrity. ${ }^{7}$

\section{Constitutional status of the agreements achieved during the Kosovo-Serbia dialogue and their different treatment by both states}

During the dialogue process, between 2011 and 2015, some twenty agreements were reached. The majority of these were concluded during the period when the dialogue process was led by government delegates, thus at a technical level; while the most important, i.e. those with impact and constitutional implications, were achieved during the period when the dialogue had turned to its phase of political dialogue (Kosovo Democratic Institute, 2018).

This section of our article seeks to address how the constitutional orders of the Republic of Kosovo and the Republic of Serbia have treated these agreements. The context here is that none of the agreements reached so far have been subject to ratification within the terms of both countries' constitutions and have, as a result, not been published in the Official Gazettes. There is only one exception, regarding the first agreement on the principles regulating the Normalisation of Relations between the Republic of Kosovo and Serbia, and that only with regard to the Republic of Kosovo. This agreement was ratified by the requisite two-thirds of the votes of the Kosovo parliament on 27 June $2013,{ }^{8}$ but it has never been ratified by the Serbian parliament.

4 Resolution of the Parliament of the Republic of Kosovo No. 04-R-08, Prishtina, 18 October 2012.

5 Kosovo's Prime Minister was then Mr. Hashim Thaçi while the Serbian Prime Minister was Ivica Dacic.

6 For such a classification of the technical and political phase of the dialogue, see the graphic in Emini, D and I. Stakić (2018) Belgrade and Pristina: lost in normalisation? European Union Institute for Security Studies (EUISS), April, pp. 4-5.

7 Republic of Kosovo's platform on the interstate technical dialogue between the Republic of Kosovo and the Republic of Serbia, Prishtina, March 2011, p. 6; and the Programme of Republic of Kosovo's Government for the Brussels Dialogue / the period 2014-2018, Prishtina, 15 January 2015 , p. 6.

8 Law No. 04/L-199 on Ratification of the First International Agreement of Principles Governing the Normalisation of Relations Between the Republic of Kosovo and the Republic of Serbia. 
But how do the constitutions of Kosovo and Serbia determine the ratification and thus the status of international agreements? In general, the Constitution of the Republic of Kosovo offers a friendly approach to the status of international law (Morina et al. 2011), evidenced by a certain number of articles in the Constitution, such as Article 19. In this context, the constitutional system of Kosovo places international agreements (treaties) above legal provisions as regards their power, but below constitutional provisions (Hasani, 2015a: 14).

International agreements reached in accordance with the 1969 Vienna Convention on the Law of Treaties can be ratified in the Republic of Kosovo in two ways. Firstly, by parliament if the agreements concern: territory; peace; alliances; political and military affairs; human rights; membership of the Republic of Kosovo of international organisations; and assuming the financial obligations of the Republic of Kosovo. ${ }^{9}$ All these agreements must be ratified by a two-thirds majority. Secondly, all other agreements not falling within the scope of these categories are considered to be ratified only after being signed by the President of the Republic of Kosovo. ${ }^{10}$ It is understood that no international agreement can enter into force and become part of the legal system of the Republic of Kosovo if has not been published in the Official Gazette.

Thus, for an international agreement to form part of the legal order of the Republic of Kosovo, it must fulfil the condition of constitutional ratification and be published in the Official Gazette. However, sometimes such agreements are qualified as political agreements which do not meet the criteria for being international treaties. ${ }^{11}$ Additionally, apart from domestic ratification, we should not overlook the importance of international ratification, as referred to in Article 14 of the Vienna Convention (Hasani, 2015a: footnote 15), although this is much less our concern here.

In the Republic of Serbia, as expressed, none of the agreements reached as part of the dialogue process have been subject to the domestic constitutional ratification procedure. The Constitution of the Republic of Serbia clearly defines that the ratification of international treaties may be carried out by a majority of votes of all the members of the parliament of the Republic of Serbia. ${ }^{12}$ Moreover, the constitutional ratification of international agreements within the Republic of Serbia is also determined by that country's laws. ${ }^{13}$

One important issue as regards international agreements in the Republic of Serbia is that the Constitutional Court has the power to review whether or not they are in accordance with the Constitution. ${ }^{14}$

In terms of how these agreements between the Republic of Kosovo and that of Serbia have been constitutionally treated, is important to emphasise that, whereas the

11 'Hasani: the Kosovo-Serbia Agreement is political' Telegrafi 23 March 2012, citing interview with Enver Hasani by Koha Ditore, available at: https://telegrafi.com/hasani-marreveshjet-kosove-serbi-jane-politike/ [last accessed 10 December 2018].

12 Constitution of the Republic of Serbia 2006, Article 105 (15.6).

13 ibid. Article 99.

14 ibid. Article 167.2. 
Agreement on the Normalisation of Relations between Kosovo and Serbia was ratified by the parliament of the Republic of Kosovo, and announced in the Official Gazette, therefore forming part of the legal order, the same agreement was considered a political act by the Constitutional Court of the Republic of Serbia and thus did not meet the conditions of an international treaty having legal effect. ${ }^{15}$ This points to the different treatment between the Republic of Kosovo and Serbia as regards the same agreement signed in the mediated dialogue process.

The different constitutional treatment of the agreements reached in the dialogue may also be noticed in the manner of their implementation. Serbia has consistently shown negligence and has blocked the implementation of those agreements that have emerged. ${ }^{16}$ Implementation mainly depends on the principles of the parties' will and on good faith (Deda and Qosaj-Mustafa, 2013). This kind of approach by Serbia stems from its perception of the status of Kosovo, given that the Republic of Serbia continuously considers Kosovo, according to its Constitution, as an autonomous province and the institutions of the Republic of Kosovo as provisional self-governing institutions. Serbia recognises neither the declaration of independence of the Republic of Kosovo of 17 February 2008 nor the Advisory Opinion of the International Court of Justice on Kosovo's declaration of independence.

Such treatment of Kosovo's status as a party to the dialogue by the Republic of Serbia may also be seen in the reasoning made by its Constitutional Court in its decision of 10 December 2014, under which it did not accept the government's request to review the constitutionality of the first Agreement on the principles for the Normalisation of Relations between Kosovo and Serbia. The grounds for this were as expressed: namely that Kosovo is a constitutional part of Serbia at the provincial level and that the institutions of Kosovo are no more than provisional self-governing institutions, while Kosovo itself is referred to as 'the so-called Republic of Kosovo'. Serbia in this way contests the reality created after 17 February 172008 when Kosovo was declared independent and sovereign. ${ }^{17}$

15 'Conclusion of 10 December 2014 for the denial of the proposal for the evaluation of the constitutionality of the first agreement on the principles for the normalisation of relations between Kosovo and Serbia, 19 April 2013' Official Gazette of the Republic of Serbia No. 13/2015, available at: http://www.ustavni.sud.rs/page/predmet/sr-Cyrl-CS/11165/?NOLAYOUT $=1$ [last accessed 4 January 2019].

16 See further Report on the implementation of the Brussels agreements Ministry of Dialogue of the Republic of Kosovo, 1 January - 15 June 2016. From the content of the report and the condition of the implementation of some of the agreements achieved in the process of dialogue, it is evident that they have been blocked by the Republic of Serbia.

17 See further 'Conclusion of $10.12 .2014 \ldots$ '. op. cit. See also: МилошПрица, МА АсистентПравногфакултета, Универзитет у Нишу 'ЗАКљУЧАК УСТАВНОГ СУДА О ОДБАЦИВАњУ ПРЕДЛОГА ЗА ОЦЕНУ УСТАВНОСТИ И ЗАКОНИТОСТИ ПАРАФИРАНОГ „ПРВОГ СПОРАЗУМА О ПРИНЦИПИМА КОЈИ РЕГУЛИШУ НОРМАЛИЗАЦИЈУ ОДНОСА' ИЗМЕЪУ ВЛАДЕ РЕПУБЛИКЕ СРБИЈЕ" UDK: 342.565.2:340.142(497.11) Радпримљен: 14.4.2015. Радприхваћен: 4.5.2015, pp. 230-233. 
Consequently, the agreements reached in the dialogue did not have the nature of actions such as that of the Prespa ${ }^{18}$ Agreement, for example, reached on 12 June 2018 between the Former Yugoslav Republic of Macedonia and Greece. This Agreement, which aims at changing the name of the country after its ratification in the Macedonian Parliament and through a referendum, enables the Greek state then to ratify the treaty allowing Macedonia's membership of NATO. ${ }^{19}$ In the case of the agreements reached between Kosovo and Serbia, there is no such interactive nature under which one party needs to take a specific step to open the way for the actions of the other. In particular, if we look at the actions undertaken regarding the implementation of these agreements, it is clear that the Serbian state has always expected the initial actions to be taken by the Republic of Kosovo, itself remaining in a passive position.

Constitutional implications of agreements deriving from the dialogue between the Republic of Kosovo and that of Serbia

The process of the dialogue has had a series of constitutional implications and consequences, especially in the Republic of Kosovo which has consistently dealt more seriously with the obligations of the dialogue process than Serbia. The latter has treated the agreements as political acts, linked to the political nature of the dialogue process, and which do not have the form of an international obligated treaty as defined in Article 2 of the Vienna Convention.

As regards Kosovo, the first constitutional implication in relation to the dialogue is related to its constitutional ratification of the Agreement on the Normalisation of Relations. Once this agreement had been ratified and proclaimed in the Official Gazette, it became part of the legal system and, in consequence, the Republic of Kosovo has undertaken obligations to implement it. ${ }^{20}$

Among other things, the Agreement on the Normalisation of Relations obliges the Republic of Kosovo to establish an Association of Serb-majority Municipalities. Out of the more than thirty agreements emerging from the whole dialogue process thus far (Kosovo Democratic Institute, 2018: 16-17), this has turned out to have had the biggest consequence or constitutional implication since, concerning the framework setting out the creation and functioning of this Association between Kosovo and Serbia, another agreement had to be signed. This agreement was signed in 2015 by the two former prime ministers of Kosovo and Serbia ${ }^{21}$ and has been properly rat-

18 Final Agreement for the settlement of the differences as described in the United Nations Security Council Resolutions 817 (1993) and 845 (1993), the termination of the Interim Accord of 1995, and the establishment of a Strategic Partnership between the Parties 12 June 2018.

19 After the ratification of the Agreement by Macedonia, Greece will ratify the Protocol for Macedonia's membership of NATO (Article 2(1) of the Agreement).

20 Constitution of the Republic of Kosovo, 2008; Article 18.1 and Article 19.1.

21 Agreement on the Association of Serb-majority Municipalities in Kosovo (2015) 25 August 2015. 
ified by the parliament of the Republic of Kosovo. ${ }^{22}$ From a legal perspective, the Agreement on the establishment of the Association of Serb-majority Municipalities is considered as facilitative legislation of the first agreement (Hasani, 2015b).

The signing of this second agreement spurred debate on the political and professional scene in the Republic of Kosovo, which initially cast doubt on whether it contravened the Constitution since it gave the Association of Serb-majority Municipalities executive competences and supra-constitutional power, as well as a role that could also affect the powers of the central government of the Republic of Kosovo. ${ }^{23}$ Opposition political parties organised a petition opposing this agreement establishing the Association on such a basis, on the grounds that it paved the way for the partition of Kosovo despite the international borders being legitimised by Kosovo's Declaration of Independence. ${ }^{24}$

In the midst of this unclear legal situation, and the huge dilemma that the second agreement sparked in Kosovo concerning the degree of its constitutional compliance, the President of the Republic of Kosovo, her Excellency Atifete Jahjaga, requested the Constitutional Court evaluate the compatibility between the principles of the Agreement and Article 3.1 and Chapters II and III of the Constitution of the Republic of Kosovo. The President submitted this request on 31 October 2015, more than two months after the signing of the agreement. Her request was based on the constitutional competence to send such issues to the Constitutional Court, pursuant to Article 84.9 in conjunction with Article 112 of the Constitution. ${ }^{25}$

The Constitutional Court found in December 2015 that the Agreement was not fully in line with the spirit of the Constitution reflected in no fewer than eighteen of its articles. ${ }^{26}$ Among other things, the Judgment set down instructions for the government regarding which articles of the Constitution should be taken into account when establishing the Association. However, academic debate in Kosovo considered the Judgment as having given confusing and hypothetical instructions to the government of the Republic of Kosovo on the manner of implementing the obligations deriving from the second agreement (Hasani, 2015a: 26).

The whole situation created in the Republic of Kosovo regarding the establishment of the Association of Serb-majority Municipalities gave strength to the notion that the Kosovo-Serbia dialogue had major constitutional implications and, as such,

22 Law No. 04/L-199 on Ratification of the First International Agreement of Principles Governing the Normalisation of Relations Between the Republic of Kosovo and the Republic of Serbia, points 1-6.

23 'The Association without executive competences' Zëri 8 July 2015, available at: https://zeri .info/aktuale/41033/asociacioni-pa-kompetenca-ekzekutive/ [last accessed 5 January 2019].

24 'The opposition in Kosovo with petition against the agreements with Serbia' Radio Free Europe 18 September 2015, available at: https://www.evropaelire.org/a/27255557.html [last accessed 5 January 2019].

25 Constitutional Court of the Republic of Kosovo (2015) Judgment No. K0130/15, sent by the President of the Republic of Kosovo, Prishtina, 23 December 2015, No. Ref: AGJ877/15 (for the procedure in the Court, see paragraphs 6 and 7).

26 Specifically, Articles 3, 7, 12, 21, 44, 57, 59, 60, 61, 62, 79, 81, 93, 101, 112, 123, 124 and 127. 
created specific consequences in Kosovo given that the process of establishing the Association therefore had to take another legal path. Despite the findings of the Constitutional Court, it is understood that the obligation to establish the Association is an international obligation that Kosovo has had to undertake after ratifying the agreement and from which it cannot escape.

The level of transparency within the Kosovo-Serbia dialogue process is a negative characteristic that has marred this process from the beginning, but there have been other signed agreements indirectly affecting the constitutional system although there has been no evaluation of them by the Constitutional Court.

In this regard, it is worth mentioning the Justice Agreement of 9 February 2015, according to which a unit of the Court of Appeal will be set up in the northern part of Mitrovica. ${ }^{27}$ The main issue here is that, under Article 21 of the Law on Courts of the Republic of Kosovo, the Court of Appeal has jurisdiction throughout the entire territory of Kosovo and that its seat is in Prishtina. The existence of a unit of the Court of Appeal contradicts this provision and somewhat disrupts the principle of a single judicial system, while it also contradicts the internal organisation of the Court of Appeal itself. ${ }^{28}$

However, considering that all the other agreements have not been ratified and have not been published in the Official Gazette, they will not be reviewed in this article as regards its consideration of their implications and possible constitutional consequences.

What does need to be re-emphasised here, though, is that the Republic of Kosovo has made the Agreement on the Normalisation of Relations a part of its legal system through its constitutional ratification. Kosovo has consequently undertaken the obligations to establish the Association of Serb-majority Municipalities, integrate Serbia's security structures into the Kosovo Police, organise elections in municipalities, etc. $^{29}$ The Republic of Kosovo has been quite responsible in the implementation of these obligations ${ }^{30}$ despite a lack of reciprocity in the Republic of Serbia.

Kosovo's obligations as regards establishing the Association of Serb-majority Municipalities have not yet been completed due to the findings of the Constitutional Court. However, this is an obligation that Kosovo has to fulfil, while bearing in mind the suggestions made by the Constitutional Court, and in this way it has undertaken some specific steps towards establishing the Association by creating a management

27 Point 11 of the Agreement on Justice concluded 9 February 2015 in Brussels. The unofficial text is published on Koha.Net under the headline 'The text of Kosovo-Serbia Agreement on the Judiciary' 11 February 2015.

28 Law No. 06/L-054 on Courts, dated 18 December 2018, Articles 21 and 24.

29 Law No. 04/L-199 on Ratification of the First International Agreement of Principles Governing the Normalisation of Relations Between the Republic of Kosovo and the Republic of Serbia, especially points 1-12 of agreement's text.

30 Bahri Cani (2016) 'Bojiq: Serb policemen from the parallel structures have been integrated!' interview for Deutsche Welle with the chief of Kosovo Police in the North, Zhelko Bojiq, 24 November 2016, available at: https://www.dw.com/sq/bojiq-polic\%C3\%ABt-serb\% C3\%AB-nga-strukturat-paralele-jan\%C3\%AB-integruar/a-36500191 [last accessed 5 January 2019]. 
team to handle its establishment. ${ }^{31}$ However, according to public and professional opinion in Prishtina, there has been a constant fear of the creation of such an Association with executive powers and that this is unconstitutional. ${ }^{32}$ Nevertheless, subsequent to the establishment of the Association, Kosovo will fulfil an international and constitutional obligation undertaken in 2013 with the Agreement on the Normalisation of Relations.

In the Republic of Serbia, as we have seen, the dialogue process has been seen rather as a political process in which Serbia has contested its equal placing with Kosovo within it, not recognising Kosovo as a state but as part of Serbia. This factor has led to the creation of clear barriers to the implementation of the treaties, but also to treating the agreements that have emerged from the dialogue as political acts with no legal effect and which do not meet the requirements for being international treaties. This has been done via the decision of its Constitutional Court, in line with Article 167 of its Constitution which sets out the jurisdiction enjoyed by the Court. ${ }^{33}$ In this way, Serbia has not accepted the agreements emerging from the dialogue as an international obligation and has implemented them in a selective manner and with a much lower level of dynamism than Kosovo.

In addition, as regards the other constitutional implications of the agreements that have emerged from the dialogue process, it is worth noticing that the Constitutional Court of Serbia has ruled against the agreements on diplomatic and cadastral records (Dërvashin, 2014: 9). Also, the decisions of the Constitutional Court of Serbia have challenged other agreements reached in the framework of the dialogue, among other things setting out that:

The instruction for controlling the passage of the administrative line in the direction of the autonomous province of Kosovo and Metohija (Official Gazette of RS No. 98/11) is not in accordance with the Constitution. The Court rejects the request for the suspension of the implementation of certain acts and actions carried under the aforementioned instructions (Case IU-224/2013). ${ }^{34}$

31 'The managing team for the establishment of the association of Serb-majority municipalities has been formed' Kosova Press news agency 8 September 2016, available at: http://ww w.kosovapress.com/sq/lajme/formohet-ekipi-menaxhues-per-themelim-e-asociacionit-te-ko munave-serb-85191/ [last accessed 5 January 2019].

32 Bekim Bislimi (2018) 'The association without executive competences' Radio Free Europe 12 May 2018, available at: https://www.evropaelire.org/a/asociacioni-kompetencat-kosova/ 29221750.html [last

accessed 5 January 2019]. For a similar approach, see also the declaration of Serbian politicians in Kosovo: 'Rashiq: I don't expect the association to have executive competences' Info Globi 18 August 2018, available at: https://infoglobi.com/rashiq-nuk-pres-qe-asociacio ni-te-kete-kompetenca-ekzekutive/ [last accessed 5 January 2019].

33 'Conclusion of 10 December 2014 for the denial of the proposal for the evaluation of the constitutionality of the first agreement on the principles for the normalisation of relations between Kosovo and Serbia, 19 April 2013' Official Gazette of the Republic of Serbia No. 13/2015, available at: http:/www.ustavni.sud.rs/page/predmet/sr-Cyrl-CS/11165/?NOLAY OUT $=1$.

34 Report of the Republic of Kosovo's Diplomatic Mission in Belgrade, sent to Republic of Kosovo's Ministry of Foreign Affairs, 1 April 2015. 
Out of the entire process of the dialogue, what has been discussed in certain cases in public opinion in Serbia is the amendment of the Serbian Constitution to enable the removal from its clauses of references to Kosovo as an autonomous province. ${ }^{35}$ The willingness to remove Kosovo from the Constitution of Serbia, respectively the Preamble and Articles 8 and 182, has not been seen to be a result of the influence of the dialogue on public opinion, but rather the outcome of the pressure and the requirements put forward by the European Union stemming from the prospective EU membership of Serbia. ${ }^{36}$

The different perception of Serbia regarding the dialogue, especially in terms of the obligations imposed by the agreements that have been reached, has consistently been a challenge in the normalisation of relations between Kosovo and Serbia.

We should emphasise that Kosovo has assumed obligations for the dialogue process as a result of the Stabilisation and Association Agreement concluded with the European Union and ratified by parliament in November 2015. ${ }^{37}$ Article 13.3(a) of the SAA stipulates, inter alia, that:

Kosovo must constantly implement in good faith all the agreements reached in the dialogue with Serbia.

The process of normalising relations between Kosovo and Serbia via the dialogue is, therefore, already a contractual obligation of Kosovo undertaken through the SAA and on its road to EU membership. ${ }^{38}$ This is also the case for the Republic of Serbia.

Is the dialogue process heading towards its final phase?

The process of dialogue for the normalisation of relations between the Republic of Kosovo and that of Serbia began almost eight years ago, but has had different stages and intensity of development. This has also reflected the level of co-operation between the parties but also the implementation of the agreements that have been reached. In most cases, the Republic of Serbia had shown itself to be destructive, while its diplomacy has often even committed itself to the utmost in terms of preventing the Republic of Kosovo from joining international organisations, including Interpol and UNESCO (Kosovo Democratic Institute, 2018: 11).

In 2016 and 2017, following the conclusion of the second agreement on the establishment of the Association of Serb-majority Municipalities, the dialogue process slowed.

Following the election of a new government on 9 September 2017, Kosovo appointed a responsible person for the technical dialogue and this was also done by the

35 Stojanović, Marija (2017) 'Serbia deletes Kosovo's autonomy from the Constitution' Danas 17 October.

36 ibid.

37 Bekim Shehu (2015) 'Kosovo's Parliament ratifies the SAA' Deutsche Welle albanian 2 November 2015, available at: https://www.dw.com/sq/kuvendi-i-kosov\%C3\%ABs-ratifiko n-marr\%C3\%ABveshjen-e-msa-s\%C3\%AB/a-18821725 [last accessed 6 January 2019].

38 Article 13 of the Stabilisation and Association Agreement between Kosovo*, on the one side, and the European Union and EURATOM, on the other, 2015. 
Republic of Serbia. ${ }^{39}$ However, the Republic of Serbia has continued to act in the same way. ${ }^{40}$

The beginning of 2018 found the dialogue in a silent phase without progress, in which the parties exchanged statements with each other regarding the non-fulfilment of the two-sided obligations. In the course of 2018, there were meetings at presidential level during which the Republic of Serbia mainly alluded to the non-fulfilment of the obligations regarding the lack of establishment of the Association of Serb-majority Municipalities (thus making the European Union also responsible). This position of Serbia appeared through the statements of President Vučić. ${ }^{41}$ Meanwhile, the statements of the Republic of Kosovo, represented by President Thaçi, alluded to the need to have an agreement on the normalisation of relations between the two states in order to facilitate the lives of their citizens. ${ }^{42}$

From the actions and declarations of state officials in the Republic of Kosovo and Serbia following the stagnation in the dialogue process, it seems that this process is now entering its final stages. We do not yet know how it will be concluded and what will be discussed in the final stage, but there have been statements on the issue of the borders between the states, and that this should be a part of the agreement between Kosovo and Serbia as a means of addressing this controversial issue. ${ }^{43}$ There has been talk in Kosovo about a legally-binding final agreement to conclude the process, ${ }^{44}$ although there is still no clear, official agenda platform either in Kosovo or in Serbia as regards a position in the final stage or even, in the case of Serbia, its view of whether this indeed represents the dialogue's final stage. Nevertheless, Kosovo has defined its recognition by Serbia as a key principle and a requirement if the dialogue is to be seen as a success, ${ }^{45}$ while a resolution of the parliament in October 2018 envisaged the drafting of a final platform although this has not yet seen the light of day.

39 'Avni Arifi named head of negotiations with Serbia' Koha.Net 12 January 2018, available at: https://www.koha.net/arberi/68765/avni-arifi-emerohet-shef-i-negociatave-me-serbine/ [last accessed 5 January 2019].

40 'Belgrade-Pristina dialogue continues at technical level' B92, 15 January 2018, available at: https://www.b92.net/eng/news/politics.php?yyyy=2018\&mm=01\&dd=15\&nav_id=103 267 [last accessed 6 January 2019].

41 'No Progress Reported In Kosovo, Serbia Normalisation Talks' Radio Free Europe, 24 March 2018, available at: https://www.rferl.org/a/no-progress-reported-talks-vucic-thaci-no rmalize-relations-kosovo-serbia-brussels/29120862.html [last accessed 6 January 2019].

42 ibid.

43 See further MacDowall, Andrew (2018) 'Could land swap between Serbia and Kosovo lead to conflict?’ The Guardian 22 August 2018, available at: https://www.theguardian.com/wor 1d/2018/aug/22/serbia-kosovo-could-land-swap-between-lead-conflict [last accessed 6 January 2019].

44 'The final agreement Kosovo-Serbia, with an obligatory nature' Zëri 3 May 2018, available at: https://zeri.info/aktuale/197392/marreveshja-perfundimtare-kosove-serbi-me-fuqi-detyr uese/ [last accessed 6 January 2019].

45 Resolution of the Parliament of the Republic of Kosovo No. 06-R-015, Prishtina, 15 December 2018. 
The parliament of Kosovo issued a new resolution on 15 December 2018 defining the framework of the dialogue and proposing a draft law to transform the comprehensive state delegation for the dialogue into a separate body to lead and manage the dialogue in the final stage. ${ }^{46}$ This, too, points towards a conclusion taking place in the near future.

However, in order to respond to Serbia's negligence in the dialogue process, Kosovo has recently imposed a 100 per cent tax on all products imported from Serbia into Kosovo. ${ }^{47}$ Such a move has considerably aggravated the readiness to continue towards the closing phase of the dialogue.

What might the final agreement contain, seen from the perspective of the Republic of Kosovo?

As we have seen, it is still unclear as to what will be negotiated in the final stage of this process and what the potential final agreement as an outcome of this process might contain. In this regard, as far as Kosovo is concerned, we know only that there is an obligation set out in the EU Stabilisation and Association Agreement that Kosovo should address the unresolved issues with Serbia through dialogue, ${ }^{48}$ although these can, in practice, be numerous.

One thing that should be clear for the Republic of Kosovo in the process of dialogue is the requirement for a change in Serbia's position such that the final dialogue is regarded as an interstate dialogue which implies recognising the independence of Kosovo as an international subject. Serbia has never done this since, in terms of its domestic legal order, it has continuously treated Kosovo as an integral part and Kosovo's institutions as temporary institutions of self-government. If this is not clarified, then the legal nature of the final agreement will be a considerable problem.

Given the numerous issues that remain unresolved in the dialogue thus far, but also on the mutual issues of Kosovo and Serbia, there is a firm presumption also that the text of the final agreement should be detailed and provide precision on all matters which have been the subject of negotiation during the dialogue.

It is important that the final agreement between Kosovo and Serbia should have the form of an obligatory international treaty between the two states, as foreseen in the Vienna Convention on the Law of Treaties. ${ }^{49}$ This means that the final agreement should have the same legal status within both of the parties to the dialogue. Furthermore, the final agreement must proceed to proper ratification, both in the Republic of Kosovo and in Serbia, in line with the constitutions of both states. ${ }^{50}$ If the final agreement is not equally treated by both parties, and is not ratified under the same constitutional procedures and published in the Official Gazettes of both states, it is

ibid.

Government of the Republic of Kosovo Decision No. 01/76, dated 21 November 2018. Article 13, paragraph 3(c) of the Stabilisation and Association Agreement between Kosovo*, on the one side, and the European Union and EURATOM, on the other, 2015.

Article 2.1(a) of the Vienna Convention on the Law of Treaties, 1969.

Constitution of the Republic of Kosovo, 2008; and the Constitution of the Republic of Serbia, 2006. 
difficult to believe that there will be a successful conclusion to the dialogue process which results in actual reconciliation.

From what we have seen so far, the Republic of Kosovo has made it clear that the final agreement with Serbia cannot affect the territorial integrity, the sovereignty of the Republic of Kosovo, the unitary character of the state and also its constitutional regulation. This has been emphasised in all the documents that the parliament and the government have prepared for the dialogue process so far, and this has also been made clear in parliament's resolution of October 2018.

In relation to the dialogue and the final agreement, efforts have been made within professional legal opinion in Prishtina to draw some conclusions on what would be the issues that Kosovo should seek to resolve in this process as a minimum, and which should also be a part of the agreement. In this regard, the analysis of the Group for Legal and Political Studies, among others, highlights some issues that could constitute the basic content of the final agreement between Kosovo and Serbia. Included in the issues identified by the Group (GLPS, 2018) are:

- full legal recognition of the Republic of Kosovo by the Republic of Serbia

- abolition of UN Resolution 1244

- judicial settlement of conflicts in any case of the non-implementation of the agreement

- an agreement which encompasses the EU as a third party

- a certain status for KFOR forces in the Republic of Kosovo

- reciprocity in the issue of the position of minority communities

- resolving the issue of missing persons.

Naturally, any process of reconciliation cannot be considered closed if there is no recognition of the statehood and independence of the Republic of Kosovo, resulting in the establishment of diplomatic relations between the two states and in accordance with the 1961 Vienna Convention on Diplomatic Relations, although this, from the statements of Serbia's representatives, currently seems impossible..$^{51}$

Inevitably, another issue which must be defined in the final agreement is the abolition of UN Security Council Resolution 1244 and the acquisition of a seat in the UN for Kosovo. This would be an important step in completing Kosovo's statehood and is something that the Kosovo parliament has made clear in its most recent resolution.

Given that Serbia has not acted correctly, and has practically been irresponsible in implementing the agreements deriving from the dialogue, the final agreement should also provide an effective judicial, or other, mechanism that would ensure that the final agreement of the dialogue is fulfilled:

One form of expressing this guarantee is for the Agreement to include a clause recognising the jurisdiction of the ICJ to adjudicate and subsequently resolve any dispute between the parties, including the compulsory enforcement of its decisions, in cases where one party avoids the obligations given in the agreement, or its purpose. (GLPS, 2018)

51 'Serbia Will Not Recognise Kosovo Despite New 100\% Tariffs - President Vučić' Sputnik 23 November 2018, available at: https://sputniknews.com/europe/201811231070055956-se rbia-kosovo-recognition-tariff-hike/ [last accessed 7 January 2019]. 
Apart from the judicial mechanism offered by the ICJ, another mechanism can also be established in order to guarantee the implementation of this agreement, including a role for the EU, which may impose sanctions on Kosovo or Serbia's EU membership process in the event of any failure to comply with the obligations arising from the final agreement. However, this issue needs to be clearly and precisely defined in the agreement.

Another aspect which must also be defined in the final agreement is Serbia's support for Kosovo expressed in the context of not creating real obstacles in practice to Kosovo's membership of international organisations and its access to international mechanisms. This also implies that Serbia itself must take specific actions.

The issue of missing persons remains a suspended topic since it was discussed in the Vienna talks and, as a result, was included in the Ahtisaari Plan under which Kosovo declared independence on 17 February 2008. ${ }^{52}$ Other unresolved problems with Serbia which could be included in the final agreement encompass legacy and pending economic and property issues, as well as the issue of international debt. The return of certain archaeological and ethnological artifacts of Kosovo, taken away by Serbia, is another problem that must be dealt with in the negotiations in the final stage of the dialogue process and which must form part of the final agreement. ${ }^{53}$

The final agreement must also regulate, in a way that is legally binding, the legal status of all the agreements that have so far been concluded in the dialogue process. Such a clause would help the parties regulate the legal status of the obligations so far entered into, and would ensure the efficient implementation and recognition of the factual consequences of the agreements signed in the dialogue.

Another issue is the creation and status of the Association of Serb-majority Municipalities in the Republic of Kosovo. This obligation, pending since 2013, should take its form in the concluding agreement of the dialogue which must regulate it in detail. The Kosovar side should be careful to do so by respecting its own Constitution as well as the findings of the judgment of its Constitutional Court on 23 December 2015. Perhaps one of the greatest challenges within this agreement will be the legal status and the position of the Association in the constitutional order of the Republic of Kosovo, given the clear tendency on the part of the Serbian side for the ethnic use of this mechanism.

\section{A final agreement that can produce constitutional changes}

One important issue in relation to the final agreement is the question of whether this agreement will produce constitutional changes in the Republic of Kosovo and the Republic of Serbia. Once the platform of topics to be discussed in the final dialogue process becomes clear, this issue is more easily addressable.

However, there continues to be a difficulty over the Association of Serb-majority Municipalities, over which there exists a risk that the content of the final agreement in relation to the design of the Association will lead to changes in the Constitution of

Article 5 of the Comprehensive Proposal for the Agreement on Kosovo's Final Status, 2 February 2007. 
the Republic of Kosovo. Furthermore, taking into account the position of the parties in the dialogue, it may happen that the Association causes a re-design of the constitutional rights of the Serb community in the Republic of Kosovo.

On the other hand, as regards the possible constitutional changes that the final agreement can produce as a minimum then, if this agreement is concluded in accordance with the Vienna Convention on the Law of Treaties, under which the Serbia recognises the sovereignty of Kosovo, it is understood that the Constitution of the Republic of Serbia will change in terms of the removal of the Republic of Kosovo from its Constitution and its Preamble. However, in the light of this, in removing Kosovo from the Constitution of the Republic of Serbia, it might potentially be the case that the Republic of Serbia treats the Association of Serb-majority Municipalities established in the Republic of Kosovo as an integral part of its Constitution. This is based on the argument of co-operation between the Serb-majority municipalities and the Republic of Serbia, including the financing of these municipalities. Such a thing is also defined in the Ahtisaari Plan on the basis of which the independence of the Republic of Kosovo was proclaimed. ${ }^{54}$ If a part of the text of the final agreement of the dialogue also refers to the rights of ethnic Albanians living in the Republic of Serbia, then this issue could potentially affect the content of the Constitution of Serbia.

Within the framework of the final agreement, the Republic of Kosovo should aim not to adjoin any of the guarantees provided by the Ahtisaari Plan for the state of Kosovo in any respect. Any adjoin to these guarantees would ruin the Ahtisaari concept and Kosovo's statehood itself. Even if there may be constitutional changes in the Republic of Kosovo deriving from the agreement, care should be taken to ensure that they do not go beyond what is contained in the Ahtisaari Plan. This principle would protect the sovereignty, statehood and constitutional system of the Republic of Kosovo.

\section{Conclusion}

The process of normalising relations between the Republic of Kosovo and the Republic of Serbia, which is about to come to an end after eight years, should produce a final agreement which will be an international treaty mandatory for both states, thus facilitating reconciliation between Kosovo and Serbia. Such reconciliation must be based on the states resolving the remaining issues and normalising their relations as two independent states and as international subjects.

What will be important in concluding the dialogue process concerns the content of the final agreement, its implementation mechanisms and its obligations; and whether this agreement will produce various constitutional changes in the Republic of Kosovo and the Republic of Serbia, or otherwise touch the sovereignty of both states.

54 ibid. Articles 10 and 11, Annex III. These articles have now been integrated in the applicable laws of the Republic of Kosovo. 


\section{References}

Deda, I and A. Qosaj-Mustafa (2013) 'Analysis of the implementation of the technical agreements between Kosovo and Serbia' Political Analysis 13(2), June, Kosovar Institute for Policy Research and Development - KIPRED.

Dërvishaj, Valdrin (2014) The legislative impact of the Kosovo-Serbia Agreement of April Centre for Education, KIPRED, July.

Emini, D and I. Stakić (2018) Belgrade and Pristina: lost in normalisation? European Union Institute for Security Studies (EUISS), April.

Group for Legal and Political Studies - GLPS (2018) What is the minimum platform for the final phase of the dialogue between Kosovo and Serbia? Prishtina, November-December 2018.

Hasani, E (2015a) 'The case of the Serbian Association in Kosovo's Constitutional Court' E DREJTA/LAW 1(4).

Hasani, E (2015b) 'The agreement recognises constitutional-making power in the Association!' Arbresh.info, 4 November 2015, available at: http://www.arbresh.in fo/opinione/enver-hasani-marreveshja-ia-njeh-pushtetin-kushtetuteberes-asociaci onit/.

Kosovo Democratic Institute (2018) Kosovo-Serbia dialogue: Challenges and the road forward, Short Analysis, March.

Morina, V, F. Korenica and D. Doli (2011) 'The relationship between international law and national law in the case of Kosovo: A constitutional perspective' I CON 9(1): 274-296, Oxford University Press and New York University School of Law.

\section{Official documents}

Agreement on the Association of Serb-majority Municipalities in Kosovo (2015) 25 August 2015.

Agreement on Justice concluded 9 February 2015 in Brussels. The unofficial text is published on Koha.Net under the headline 'The text of Kosovo-Serbia Agreement on the Judiciary' 11 February 2015.

Comprehensive Proposal for the Agreement on Kosovo's Final Status, 2 February 2007 (Ahtisaari Plan).

'Conclusion of 10 December 2014 for the denial of the proposal for the evaluation of the constitutionality of the first agreement on the principles for the normalisation of relations between Kosovo and Serbia, 19 April 2013' Official Gazette of the Republic of Serbia No. 13/2015, available at: http://www.ustavni.sud.rs/page/pre dmet/sr-Cyrl-CS/11165/?NOLAYOUT=1.

Constitution of the Republic of Kosovo, 2008.

Constitution of the Republic of Serbia, 2006. 
Constitutional Court of the Republic of Kosovo (2015) Judgment No. K0130/15, sent by the President of the Republic of Kosovo, Prishtina, 23 December 2015, No. Ref: AGJ877/15.

Final Agreement for the settlement of the differences as described in the United Nations Security Council Resolutions 817 (1993) and 845 (1993), the termination of the Interim Accord of 1995, and the establishment of a Strategic Partnership between the Parties 12 June 2018 [Prespa Agreement].

Government of the Republic of Kosovo Decision No. 01/76, dated 21 November 2018.

International Court of Justice Reports of Judgments, Advisory Opinions and Orders in Accordance with International Law of the Unilateral Declaration of Independence in Respect of Kosovo Advisory Opinion, 22 July 2010.

Law No. 04/L-199 on Ratification of the First International Agreement of Principles Governing the Normalisation of Relations Between the Republic of Kosovo and the Republic of Serbia.

Law No. 06/L-054 on Courts, dated 18 December 2018.

Programme of the Government of the Republic of Kosovo for the Brussels Dialogue for the period 2014-2018 Prishtina, 15 January 2015.

Report of the Republic of Kosovo's Diplomatic Mission in Belgrade, sent to Republic of Kosovo's Ministry of Foreign Affairs, 1 April 2015.

Report on the implementation of the Brussels agreements Ministry of Dialogue of the Republic of Kosovo, 1 January - 15 June 2016.

Republic of Kosovo's platform on the interstate technical dialogue between the Republic of Kosovo and the Republic of Serbia Prishtina, March 2011.

Resolution adopted by the General Assembly [without reference to a Main Committee (A/64/L.65/Rev. 1)] 64/298: Request for an advisory opinion of the International Court of Justice on whether the unilateral declaration of independence of Kosovo is in accordance with international law, 9 September 2010.

Resolution of the Parliament of the Republic of Kosovo No. 04-R-001, Prishtina, 10 March 2011.

Resolution of the Parliament of the Republic of Kosovo No. 04-R-08, Prishtina, 18 October 2012.

Resolution of the Parliament of the Republic of Kosovo No. 06-R-015, Prishtina, 15 December 2018.

Settlement of the difference on the name, the pending issues related to it and entrenchment of good neighbourly relations 12 June 2018.

Stabilisation and Association Agreement between Kosovo*, on the one side, and the European Union and EURATOM, on the other, 2015.

Vienna Convention on the Law of Treaties, 1969. 
Vienna Convention on Diplomatic Relations, 1961.

МилошПрица, МА АсистентПравногфакултета, Универзитет у Нишу 'ЗАКЉУЧАК УСТАВНОГ СУДА О ОДБАЦИВАњУ ПРЕДЛОГА ЗА ОЦЕНУ УСТАВНОСТИ И ЗАКОНИТОСТИ ПАРАФИРАНОГ „ПРВОГ СПОРАЗУМА О ПРИНЦИПИМА КОЈИ РЕГУЛИШУ НОРМАЛИЗАЦИЈУ ОДНОСА' ИЗМЕЂУ ВЛАДЕ РЕПУБЛИКЕ СРБИЈЕ" UDK: 342.565.2:340.142(497.11) Радпримљен: 14.4.2015. Радприхваћен: 4.5.2015.

\section{Media and online sources}

'Avni Arifi named head of negotiations with Serbia' Koha.Net 12 January 2018, available at: https://www.koha.net/arberi/68765/avni-arifi-emerohet-shef-i-negoc iatave-me-serbine/.

'Belgrade-Pristina dialogue continues at technical level' B92, 15 January 2018, available at: https://www.b92.net/eng/news/politics.php?yyyy $=2018 \& \mathrm{~mm}=01 \& \mathrm{~d}$ $\mathrm{d}=15 \&$ nav_id=103267.

'Hasani: the Kosovo-Serbia Agreement is political' Telegrafi 23 March 2012, citing interview with Enver Hasani by Koha Ditore, available at: https://telegrafi.com/h asani-marreveshjet-kosove-serbi-jane-politike/.

'No Progress Reported In Kosovo, Serbia Normalisation Talks' Radio Free Europe, 24 March 2018, available at: https://www.rferl.org/a/no-progress-reported-talks-v ucic-thaci-normalize-relations-kosovo-serbia-brussels/29120862.html.

'Rashiq: I don't expect the association to have executive competences' Info Globi 18 August 2018, available at: https://infoglobi.com/rashiq-nuk-pres-qe-asociacioni-t e-kete-kompetenca-ekzekutive/.

'Serbia Will Not Recognise Kosovo Despite New 100\% Tariffs - President Vučić' Sputnik 23 November 2018, available at: https://sputniknews.com/europe/201811 231070055956-serbia-kosovo-recognition-tariff-hike/.

'The Association without executive competences' Zëri 8 July 2015, available at: https://zeri.info/aktuale/41033/asociacioni-pa-kompetenca-ekzekutive/.

'The final agreement Kosovo-Serbia, with an obligatory nature' Zëri 3 May 2018, available at: https://zeri.info/aktuale/197392/marreveshja-perfundimtare-kosove-s erbi-me-fuqi-detyruese/.

'The managing team for the establishment of the association of Serb-majority municipalities has been formed' Kosova Press news agency 8 September 2016, available at: http://www.kosovapress.com/sq/lajme/formohet-ekipi-menaxhues-per-th emelim-e-asociacionit-te-komunave-serb-85191/.

'The opposition in Kosovo with petition against the agreements with Serbia' Radio Free Europe 18 September 2015, available at: https://www.evropaelire.org/a/272 55557.html. 
Bekim Bislimi (2018) 'The association without executive competences' Radio Free Europe 12 May 2018, available at: https://www.evropaelire.org/a/asociacioni-ko mpetencat-kosova/29221750.html.

Bahri Cani (2016) 'Bojiq: Serb policemen from the parallel structures have been integrated!' interview for Deutsche Welle with the chief of Kosovo Police in the North, Zhelko Bojiq, 24 November 2016, available at: https://www.dw.com/sq/b ojiq-polic\%C3\%ABt-serb\%C3\%AB-nga-strukturat-paralele-jan\%C3\%AB-integr uar/a-36500191.

MacDowall, Andrew (2018) 'Could land swap between Serbia and Kosovo lead to conflict?' The Guardian 22 August 2018, available at: https://www.theguardian.c om/world/2018/aug/22/serbia-kosovo-could-land-swap-between-lead-conflict.

Bekim Shehu (2015) 'Kosovo's Parliament ratifies the SAA' Deutsche Welle albanian 2 November 2015, available at: https://www.dw.com/sq/kuvendi-i-kosov\%C3 $\% A B s-r a t i f i k o n-m a r r \% C 3 \% A B v e s h j e n-e-m s a-s \% C 3 \% A B / a-18821725$.

Stojanović, Marija (2017) 'Serbia deletes Kosovo's autonomy from the Constitution' Danas 17 October. 
